\title{
PENGARUH IN-STORE PROMOTION TERHADAP PEMBELIAN TIDAK TERENCANA PADA SWALAYAN MOUZA DI KOTA PALU
}

\author{
Disusun oleh: \\ ${ }^{1}$ Abd Rahman, ${ }^{2}$ Kamal, \\ (Dosen Fakultas Ekonomi Universitas Alkhairaat Palu)
}

ABSTRAK

Penelitian ini bertujuan untuk mengetahui dan menganalisis seberapa besar pengaruh secara simultan dan secara parsial variabel Periklanan, Promosi Penjualan, penjualan pribadi dan Display Toko terhadap pembelian tidak terencana pada Swalayan Mouza.. Data yang digunakan dalam penelitian ini adalah data primer dan data sekunder yang diperoleh dari konsumen Swalayan Mouza yang melakukan pembelian tidak terencana, dikumpulkan melalui kuesioner, wawancara, serta studi dokumentasi yang berkaitan dengan penelitian ini. Adapun metode analisis yang digunakan adalah analisis regresi linier berganda. Hasil penelitian menunjukan hasil analisis diketahui bahwa variabel store athmosphere menunjukkan bahwa pada tingkat signifikansi t 0,000 atau lebih kecil dari pada nilai alpha 0,05 membuktikan bahwa store athmosphere merupakan elemen bauran promosi ritel yang berpengaruh signifikan terhadap pembelian tidak terencana. Dab variabel periklanan, promosi penjualan, penjualan pribadi berpengaruh signifikan terhadap pembelian tidak terencana pada Swalayan Mouza di Kota Palu.

.Kata Kunci: Periklanan, Promosi Penjualan, Display Toko dan Penjualan Pribadi.

\section{LATAR BELAKANG}

Supermarket atau pasar swalayan

adalah sebuah toko yang menjual segala kebutuhan sehari-hari. Kata yang secara harfiah yang diambil dari bahasa Inggris ini artinya adalah pasar yang besar. Barangbarang yang dijual di supermarket biasanya adalah barang barang kebutuhan sehari-hari. Seperti bahan makanan, minuman, dan barang kebutuhan seperti tissu dan lain sebagainya. Di dalam pasar tradisional atau pun pasar modern terdapat pedagang yang menjual barang atau jasa langsung kepada konsumen akhir untuk dikonsumsi. Pedagang ini disebut sebagai pedagang eceran (ritel). Terdapat banyak jenis pedagang eceran baik pedagang eceran yang menjual barang-barang berat seperti peralatan elektronik sampai pedagang eceran yang menjual kebutuhan sehari-hari seperti makanan dan pakaian

Salah satu cara yang dilakukan oleh peritel swalayan untuk mempertahankan keunggulan bersaing dan menjaga gross profit adalah dengan promosi. Promosi dapat dilakukan melalui berbagai macam jenis media baik di luar toko ataupun promosi yang dilakukan di dalam toko (in-store promotion). Promosi di luar toko dapat dilakukan dengan tujuan untuk menarik konsumen mengunjungi toko dengan cara melakukan bauran pemasaran yaitu 4P, Product, Price, Promotion, Place secara 
umum, bisa dilakukan dengan strategi, sementara promosi yang khusus dilakukan di dalam toko bertujuan untuk menjadi stimulus yang dapat merangsang keputusan pembelian konsumen di dalam toko, baik keputusan yang telah direncanakan atau pun keputusan yang belum direncanakan sebelum datang ke toko.

Pertumbuhan industri ritel di kota palu cenderung meningkat. Hal ini ditandai dengan munculnya sejumlah toko berkonsep swalayan. Permasalahan yang dihadapi oleh peritel untuk mencapai keunggulan bersaing selain pesaing adalah bagaimana menjaga keseimbangan antara barang yang dijual oleh peritel dengan barang yang dibutuhkan oleh konsumen. Tidak semua produk yang disediakan oleh peritel menarik minat konsumen, untuk itu peritel harus merumuskan strategi agar produk yang kurang diminati tersebut dapat menarik minat konsumen. Salah satu cara adalah melalui promosi di dalam toko (in-store promotion).

Penelitian ini ingin mengungkapkan strategi promosi di dalam toko manakah yang paling yang tepat yang dapat dilakukan oleh perusahaan supplier agar menciptakan pembelian tak terencana bagi konsumen yang berbelanja di swalayan Mouza.

Permasalahan yang diangkat dalam penelitian ini adalah:

1. Apakah In-store promotion yang terdiri dari dari periklanan, penjualan pribadi, display toko dan promosi penjualan berpengaruh signifikan secara simultan terhadap pembelian yang tidak terencana konsumen pada Swalayan Mouza di kota Palu.

2. Apakah Periklanan berpengaruh signifikan secara parsial terhadap pembelian yang tidak terencana konsumen Swalayan Mouza di kota Palu.

3. Apakah promosi penjualan berpengaruh signifikan secara parsial terhadap pembelian yang tidak terencana konsumen Swalayan Mouza di kota Palu.

4. Apakah penjualan pribadi berpengaruh signifikan secara parsial terhadap pembelian yang tidak terencana konsumen Swalayan Mouza di kota Palu.

5. Apakah display toko berpengaruh signifikan secara parsial terhadap pembelian yang tidak terencana konsumen Swalayan Mouza di kota Palu.

\section{KAJIAN PUSTAKA Bauran Promosi Ritel}

Promosi merupakan suatu kegiatan yang dilakukan oleh perusahaan untuk mengkomunikasikan kepada konsumen mengenai produk yang ditawarkan agar konsumen memiliki ketertarikan, keinginan, dan tindakan untuk membeli produk tersebut. Bauran promosi ritel atau yang lebih populer disebut in-store promotion merupakan alat yang dapat 
mengkomunikasikan produk kepada konsumen. Kebijakan bauran pemasaran akan lebih berhasil jika apa yang telah diprogram dikomunikasikan dengan baik yaitu dengan aktivitas promosi. Secara umum, aktivitas promosi dapat dilakukan dengan empat variabel. Keempat variabel tersebut adalah periklanan (advertising), penjualan pribadi (personal selling ), promosi penjualan (sales promotion), dan publisitas (publicity ) (Syahyunan, 2004). Menurut Lewison dan Delozier (1989) dalam industri ritel, bauran promosi terdiri dari periklanan (advertising), penjualan pribadi (personal selling), display toko (store display), promosi penjualan (sales promotion ), dan publisitas (publicity).

\section{Periklanan (Advertising)}

Iklan secara umum adalah bentuk presentasi dan promosi non pribadi tentang ide, barang dan jasa yang dibayar oleh sponsor tertentu (Syahyunan, 2004). Iklan yang dilakukan peritel merupakan komunikasi tidak langsung kepada konsumen tentang toko, produk yang ditawarkan, pelayanan atau Ide. Menurut (Salim, 2020) Iklan dilakukan dengan tujuan mempengaruhi perilaku dan persepsi konsumen tentang toko, produk, dan aktivitas peritel serta untuk mempengaruhi pembelian secara langsung atau pun tidak langsung. Media yang dapat dipilih oleh peritel diantaranya adalah media cetak, media elektronik, dan berbagai macam media lainnya termasuk point-of purchase media. Iklan sering menjadi titik kontak pertama antara pemasar dan pelanggannya. Iklan merupakan bentuk komunikasi non-pribadi yang dilakukan oleh pemasar untuk menginformasikan, mendidik, atau membujuk anggotaanggota audience sasaran. Media yang dapat digunakan untuk beriklan diantaranya adalah televisi, radio, majalah, koran, poster, reklame, dan kendaraan seperti bus. (Lovelock, 2005)

2. Penjualan Pribadi (Personal Selling)

Personal selling merupakan kegiatan perusahaan untuk melakukan kontak langsung dengan konsumennya. Kontak langsung ini diharapkan akan terjadi interaksi yang positif antara perusahaan dan konsumen (Lubis, 2004). Dalam industri ritel, personal selling adalah elemen terpenting dalam pembentukan image ritel. Ritel seperti hypermarket biasanya menggunakan Sales Promotion Girl (pramuniaga) sebagai orang pertama yang berinteraksi dengan konsumen secara langsung (tatap muka). SPG merupakan faktor yang signifikan meningkatkan total kesan konsumen (Lewison dan Delozier, 1989). Penjualan 
pribadi adalah pertemuan antar pribadi dengan tatap muka (atau dalam Lewison dan Delozier (1989) telemarketing, lewat suara), dimana berbagai upaya ditempuh untuk mendidik konsumen dan mempromosikan preferensi untuk merek atau produk tertentu (Lovelock, 2005).

\section{Display Toko (Store Display)}

Display Toko atau Penataan barang dagangan pada sebuah toko memiliki peran dan arti yang sangat penting. Sering terjadi seorang ibu yang awalnya datang ketoko untuk berbelanja Susu kental manis merek tertentu, ternyata pada Rak yang sama terdapat merek lain yang lebih murah. Melihat pada rak sebelah terdapat deretan biskuit dengan kemasan kaleng menarik serta tambahan/ hadiah kemasan karton kecil. Pada rak Sabun cuci kondisi sama, hampir semua deterjen memberikan diskon dan hadiah. Kesemua produk tersebut ditata dengan rapi dan baik serta memiliki daya tarik. Sehingga pada akhirnya ibu tersebut pulang dengan menbawa berbagai barang kebutuhan yang sebenarnya tidak ada dalam rencana belanjanya. Hal tersebut terjadi karena konsumen tersebut melihat penampilan visual yang menarik sehingga terdorong untuk melakukan impulse buying yakni pembelian seketika. menyatakan bahwa terdapat empat tipe umum dari display toko, yaitu:

a. Selection Display, yaitu pemajangan produk sesuai dengan jenis produknya.

b. Special Display, yaitu pemajangan produk untuk satu merek produk tertentu.

c. Point-of Purchase Display, yaitu display produk dengan menggunakan berbagai macam point of purchase seperti poster untuk memberikan informasi mengenai produk kepada konsumen.

d. Audiovisual Display, yaitu display produk yang menggunakan media.

\section{Promosi Penjualan (Sales Promotion)}

Promosi penjualan pada ritel disebut juga sales incentive (insentif penjualan) yaitu rangsangan baik secara langsung atau pun tidak langsung yang menawarkan nilai tambah bagi konsumen. Beberapa bentuk promosi penjualan adalah diskon (discount)), sample (tester), dan hadiah untuk pembelian produk dengan jumlah tertentu, serta iklan khusus (Lewison dan Delozier, 1989).

Menurut (Akhmad \& Latoki, 2021) Promosi penjualan dapat digambarkan sebagai komunikasi yang dikaitkan dengan insentif. Tujuannya adalah untuk mempercepat keputusan pembelian atau memotivasi konsumen menggunakan jasa tertentu lebih cepat, dalam volume yang lebih 
besar pada setiap pembelian, atau lebih sering.

Promosi harga jangka pendek dapat menawarkan keuntungan- keuntungan salah satunya adalah dapat menambah keinginan konsumen untuk melakukan pembelian ulang dan menarik bagi konsumen yang sadar akan harga (Lovelock, 2005). Alat promosi lainnya diungkapkan Totten \& Block (1994) dalam Ndubisi (2007) Typical sales promotion includes coupons, samples, in-pack premiums, price-offs, displays, and soon.

Kupon adalah sertifikat dengan nilai tertulis tertentu yang ditunjukkan kepada took pengecer guna mendapatkan pengurangan harga. Sampel atau tester adalah pemberian atau contoh produk yang diberikan kepada konsumen untuk dicoba dan gift adalah pemberian hadiah jika membeli barang dengan jumlah tertentu. Menurut Kotler (2005), promosi penjualan dapat digunakan untuk mendapatkan efek jangka pendek seperti mendramatisir tawaran produk dan meningkatkan penjualan yang merosot. Harapannya adalah perusahaan memperoleh tanggapan konsumen yang lebih kuat dan lebih cepat.

Hal senada diungkapkan oleh Cummins dan Mullin (2004 : 41-44) mengatakan salah satu tujuan dari promosi penjualan adalah menciptakan ketertarikan dan mengalihkan perhatian dari harga. Intinya ketertarikan itu akan menimbulkan gairah atau antusiasme pembeli untuk membeli suatu produk dan tetap membeli kepada toko yang bersangkutan. Mengalihkan perhatian dari harga berkaitan dengan adanya perang harga diantaranya variasi harga, promosi kolektor harga, dan membuat perbandingan harga yang tidak langsung. Promosi terhadap nilai yang menciptakan ketertarikan dan mengakibatkan pembelian tidak terencana (impulse buying).

\section{Selanjutnya David S Simatupang} (Marketing, 2007) mengatakan bahwa Tujuan dari promosi penjualan adalah meningkatkan volume penjualan jangka pendek dengan menciptakan tampilan dan aktivitas yang menarik untuk mendorong impulse buying. Tampilan ini menimbulkan suatu kegairahan untuk membeli atau merupakan suatu rangsangan tingkah laku untuk memuaskan kebutuhan hidup.

\section{Impulse Buying}

Beberapa konsumen sering kali membeli produk atau jasa tanpa direncanakan terlebih dahulu. Hal ini dapat disebabkan oleh banyak hal seperti display pemotongan harga $50 \%$. Display atau peragaan tersebut telah membangkitkan kebutuhan konsumen, sehingga konsumen merasakan kebutuhan yang mendesak untuk membeli produk yang dipromosikan tersebut. Keputusan pembelian seperti ini disebut sebagai pembelian impulse 
(impulse purchasing/impulse buying) (Sumarwan, 2002). Menurut (Azis, 2019) Setiap keputusan pembelian mempunyai motif di baliknya. Motif pembelian dapat dipandang sebagai kebutuhan yang timbul, rangsangan atau gairah. Motif ini berlaku sebagai kekuatan yang timbul yang ditujukan untuk memuaskan kebutuhan yang timbul. Persepsi seseorang mempengaruhi atau membentuk tingkah laku ini. Pemahaman akan motif pembelian memberikan alasan pada penjual mengapa pelanggan tersebut membeli .

Menurut Berman (2001) impulse buying terjadi ketika konsumen membeli produk dan/atau merek yang tidak direncanakan sebelum masuk kedalam toko, membaca katalog penawaran, melihat $\mathrm{TV}$, online di WEB, dan yang lainnya. Dengan impulse buying, pembuatan keputusan membeli oleh konsumen dipengaruhi oleh peritel. Ada tiga jenis pembelian dengan dorongan (impulse buying), yaitu:

1. Completely Unplanned (tidak terencana seluruhnya), yaitu jika konsumen tidak berniat membeli kategori produk atau jasa sebelum datang ke toko.

2. Partially Unplanned (tidak terencana sebagian), yaitu jika konsumen sudah berniat membeli kategori produk atau jasa tetapi belum menentukan merek apa yang akan dibeli sebelum mengunjungi toko.

3. Unplanned Substitution (penggantian yang tidak direncanakan), yaitu jika konsumen telah menetapkan merek apa yang akan dibeli tetapi merubah pilihannya setelah tiba di toko.

\section{Metode Penelitian}

Penelitian ini dilakukan pada objek Swalayan Mouza di Kota Palu. Penelitian berlangsung selama 6 (enam) bulan, yaitu pada Bulan Juni sampai dengan Bulan Desember 2016.

\section{Populasi dan Sampel}

Indikator yang digunakan dalam penelitian ini sebanyak 20 indikator. Sehingga didapatkan jumlah dalam penelitian ini adalah 10 x $14=140$ sampel. Sampel tersebut dianggap cukup representatif, sebab menurut Gay (Umar, 2003:147) bahwa ukuran minimal sampel yang dapat diterima minimal 30 subjek. Responden yang akan menjadi sampel dalam penelitian ini akan diambil dengan menggunakan metode Purposive Sampling. Yaitu teknik penarikan sampel dengan kriteria tertentu. Adapun kriteria yang digunakan dalam penelitian ini adalah sebagai berikut:

1. Responden merupakan konsumen yang melakukan pembelian tidak terencana di Swalayan Mouza.

2. Telah melakukan pembelian minimal 3 kali.

3. Bersedia mengisi kuesioner. 


\section{Jumal Ekgnomi Trend Vol. 09 So. 02 Jufi - Desem6er 2021 E-ISSN. 2722-6565}

4. Berusia 17 tahun ke atas

\section{Hasil dan Pembahasan Hasil Pengujian Regresi}

Hasil analisis regresi berganda dengan variabel bebas yaitu variabel periklanan (X1), promosi penjualan $(\mathrm{X} 2)$, penjualan pribadi (X3), store athmosphere (X4), dan variabel terikat yaitu pembelian tidak terencana $(\mathrm{Y})$ pada Swalayan Mouza di Kota Palu.

\section{Tabel 1}

Hasil Pengujian Regresi Linear Berganda

\begin{tabular}{|l|r|r|r|}
\hline \multicolumn{4}{|c|}{ Faktor Terikat $=\begin{array}{c}\text { Pembelian Tidak Terencana } \\
(Y)\end{array}$} \\
\hline Variabel & \multicolumn{1}{|c|}{ (Beta) } & \multicolumn{1}{c|}{ t-hit } & \multicolumn{1}{c|}{ Sig.t } \\
\hline (Constant) & -1.381 & & \\
(X1) & 0.272 & 5.378 & 0.000 \\
(X2) & 0.334 & 5.594 & 0.000 \\
(X3) & 0.181 & 3.065 & 0.003 \\
(X4) & 0.306 & 5.412 & 0.000 \\
\hline
\end{tabular}

Koefisien Determinasi $\left(\mathrm{R}^{2}\right)=0,884$

Sig.F $=0,000$

Sumber: Lampiran

Berdasarkan dari hasil pengolahan data pada Tabel 4.6 diperoleh persamaan model regresi berganda yang dibentuk adalah:

$$
\begin{gathered}
Y=-1,381+0.272 X 1+0.334 X 2+0.181 \\
X 3+0.306 X 4
\end{gathered}
$$

Persamaan regresi diatas dapat dijelaskan sebagai berikut:

a. Nilai a (constanta) adalah -1.381 berarti apabila tidak ada variabel periklanan (X1), sales promotion (X2), personal selling (X3), store athmosphere (X4) atau bernilai 0 maka total pembelian tidak terencana akan bernilai -1.381.

b. Nilai koefisien regresi variabel perikalanan (X1) 0,272 berarti terjadi pengaruh yang positif antara periklanan dengan pembelian tidak terencana. Artinya semakin baik perikalanan maka akan menaikkan kemungkinan terjadinya pembelian tidak terencana.

c. Nilai koefisien regresi variabel promosi penjualan (X2) 0,334 berarti terjadi pengaruh positif antara promosi penjualan dengan pembelian tidak terencana. Artinya semakin baik promosi penjualan maka akan menaikkan kemungkinan terjadinya pembelian tidak terencana.

d. Nilai koefisien regresi variabel penjualan pribadi (X3) 0,181 berarti terjadi pengaruh positif antara penjualan pribadi dengan pembelian tidak terencana. Artinya semakin baik penjualan pribadi maka akan menaikkan kemungkinan terjadinya pembelian tidak terencana.

e. Nilai koefisien regresi variabel store athmosphere (X4) 0,306 berarti terjadi pengaruh positif antara store athmophere dengan pembelian tidak terencana. Artinya semakin baik store athmosphere maka akan menaikkan kemungkinan 


\section{Jumal Ekgnomi Trend Vol. 09 So. 02 Jufi - Desem6er 2021 E-ISSN. 2722-6565}

terjadinya pembelian tidak terencana.

\section{Hasil Pengujian Hipotesis}

\section{Uji Simultan (Uji F)}

Hasil yang digunakan sebagai
pengujian tingkat kesesuaian model
menunjukkan Selanjutnya berdasarkan tabel 4.6. dari hasil perhitungan diperoleh Fhitung $=75.034$ dan nilai Sig F $(0.000)<0,05$. Dengan demikian jelas terlihat Sig $\mathrm{F}<$ alpha (0.05) yang berarti semua variabel bebas layak untuk menjelaskan variabel terikat yang dianalisis, sehingga dapat dimaknai bahwa semua variabel bebas yang digunakan dalam model secara bersama-sama dapat menjelaskan variabel terikat.

\section{Uji Parsial (Uji t)}

Berdasarkan hasil perhitungan statistik, dapat diinterprestasikan hasil uji- sig t sebagai berikut:

1. Untuk variabel Periklanan berdasarkan hasil penelitian diketahui bahwa elemen bauran promosi ritel yaitu variabel periklanan menunjukkan bahwa pada tingkat signifikansi t 0,000 atau lebih kecil dari pada nilai alpha 0,05 membuktikan bahwa variabel periklanan berpengaruh signifikan terhadap pembelian tidak terencana.

2. Untuk variabel promosi penjualan berdasarkan hasil penelitian diketahui bahwa elemen bauran promosi ritel yaitu variabel promosi penjualan yang disusun oleh lima indikatornya menunjukkan bahwa pada tingkat signifikansi t 0,000 atau lebih kecil dari pada nilai alpha 0,05 membuktikan bahwa variabel promosi penjualan berpengaruh signifikan terhadap pembelian tidak terencana.

3. Untuk variabel penjualan pribadi berdasarkan hasil penelitian diketahui bahwa variabel penjualan pribadi yang merupakan bauran promosi ritel menunjukkan bahwa pada tingkat signifikansi t 0,003 atau lebih kecil dari pada nilai alpha 0,05 membuktikan bahwa variabel penjualan pribadi berpengaruh positif secara signifikan terhadap pembelian tidak terencana pada Swalayan Mouza di Kota Palu.

4. Untuk variabel store athmosphere Berdasarkan hasil analisis diketahui bahwa variabel store athmosphere menunjukkan bahwa pada tingkat signifikansi t 0,000 atau lebih kecil dari pada nilai alpha 0,05 membuktikan bahwa store athmosphere merupakan elemen bauran promosi ritel yang berpengaruh signifikan terhadap pembelian tidak terencana.

\section{PEMBAHASAN}

Pengaruh variabel Periklanan, Promosi Penjualan, Penjualan Pribadi, dan Atmosfir Toko terhadap pembelian tidak terencana pada Swalayan Mouza di kota Palu 


\section{Jumal ERonomi Trend Vol. 09 SNo. 02 Jufi - Desember 2021 E-ISSN. 2722-6565}

Besarnya pengaruh keempat variabel tersebut dapat dijelaskan dari besarnya koefisien determinasi (Adjust $R$ Square) sebesar 0,884. Hal ini menunjukkan bahwa $88,4 \%$ variasi keputusan pembelian tidak terencana dapat dijelaskan oleh variasi dari keempat variabel bebas dalam penelitian ini (periklanan, promosi penjualan, penjualan pribadi, dan store athmosphere). Sedangkan sisanya sebesar $11,6 \%$ dijelaskan oleh sebabsebab yang lain di luar model.

\section{Pengaruh Variabel Periklanan Terhadap Pembelian Tidak Terencana terhadap pembelian tidak terencana pada Swalayan Mouza di kota Palu.}

$$
\text { Berdasarkan hasil penelitian }
$$

diketahui bahwa elemen bauran promosi ritel yaitu variabel periklanan menunjukkan bahwa pada tingkat signifikansi t 0,000 atau lebih kecil dari pada nilai alpha 0,05 membuktikan bahwa variabel periklanan berpengaruh signifikan terhadap pembelian tidak terencana.

Dalam penelitian ini variabel periklanan diukur melalui banner, poster, dan brosur mendapatkan penilaian positif terhadap terciptanya pembelian tidak terencana. Iklan banner ditinjau dari segi desainnya mendapatkan penilaian sangat setuju dan setuju masing-masing sebesar 33,3 $\%$ dan $51.9 \%$ dari total responden sehingga disimpulkan bahwa banner yang digunakan oleh Swalayan Mouza di Kota Palu memberikan kontribusi positif terhadap terbentuknya pembelian tidak terencana. Poster ditinjau dari bentuk dan ukurannya mendapatkan penilaian sangat setuju dan setuju masing-masing sebesar 30,6 \% dan $55,6 \%$ dari total responden sehingga disimpulkan bahwa poster yang digunakan oleh Swalayan Mouza di Kota Palu memberikan kontribusi positif terhadap terciptanya pembelian tidak terencana. Selanjutnya adalah indikator brosur yang ditinjau dari desain serta informasi yang ada didalamnya mendapatkan penilaian sangat setuju dan setuju masing-masing sebesar 34,3 $\%$ dan $55,6 \%$ dari total responden sehingga dapat disimpulkan bahwa brosur dengan desain dan informasinya mampu memberikan kontribusi positif terhadap terciptanya pembelian tidak terencana pada Swalayan Mouza di Kota Palu.

\section{Pengaruh Variabel Promosi Penjualan Terhadap Pembelian Tidak Terencana pada Swalayan Mouza di kota Palu.}

Dalam penelitian ini variabel Promosi Penjualan diukur oleh lima (5) indikator yaitu diskon, hadiah langsung, sample, demonstrasi, dan souvenir. Indikatorindikator tersebut mendapatkan penilaian positif oleh responden sehingga dianggap memberikan kontribusi dalam terciptanya pembelian tidak terencana. Diskon mendapatkan penilaian sangat setuju dan setuju masing- masing sebesar $23,1 \%$ dan 
$54,6 \%$ dari total responden sehingga disimpulkan bahwa diskon memberikan kontribusi positif terhadap terjadinya pembelian tidak terencana pada Swalayan Mouza di Kota Palu. Hadiah langsung ditinjau dari segi jumlah mendapatkan penilaian sangat setuju dan setuju masingmasing sebesar $21,3 \%$ dan $50 \%$ dari total responden sehingga disimpulkan bahwa hadiah langsung memberikan kontribusi positif. Sample dalam penelitian ini ditinjau sebagai produk yang dapat digunakan atau dicoba oleh konsumen karena diberi kesempatan oleh pihak gerai dalam rangka menarik minat konsumen terhadap suatu produk mendapatkan penilaian sangat setuju dan setuju masing masing sebesar $25,9 \%$ dan $45,4 \%$ dari total responden sehingga disimpulkan bahwa sampel memberikan kontribusi positif terhadap terjadinya pembelian tidak terencana.

Pengaruh Variabel Penjualan Pribadi Terhadap Pembelian Tidak Terencana pada Swalayan Mouza di kota Palu.

\section{Berdasarkan hasil penelitian}

diketahui bahwa variabel penjualan pribadi yang merupakan bauran promosi ritel menunjukkan bahwa pada tingkat signifikansi t 0,003 atau lebih kecil dari pada nilai alpha 0,05 membuktikan bahwa variabel penjualan pribadi berpengaruh positif secara signifikan terhadap pembelian tidak terencana pada Swalayan Mouza di Kota Palu.Variabel penjualan pribadi dalam penelitian ini di ukur dengan menggunakan dua (2) indikator yaitu Cross-Selling dan Advising, Cross-Selling, yaitu menawarkan produk yang berbeda, yang mendukung produk yang dibutuhkan oleh pembeli, karyawan mengambil produk yang berbeda untuk ditawarkan kepada konsumen dengan meperlihatkan harga serta mutu dari produk tersebut. Advising, yaitu berperan sebagai penasihat bagi pelanggannya. Tugas sebagai penasihat adalah memberikan pandangan tentang produk yang cocok untuk dikonsumsi oleh customer tersebut, terkadang banyak konsumen yang meminta saran produk apa yang cocok digunakan untuk mereka, karyawan di swalayan mouza juga membantu memilih produk yang tepat untuk konsumen gunakan dengan variasi harga dan mutu yang berbeda

\section{Pengaruh Variabel Atmosfir Toko Terhadap Pembelian Tidak Terencana}

Pengertian atmosfir toko menurut Hendri Ma'ruf (2005:201) adalah: “Atmosfir Toko adalah salah satu marketing mix dalam gerai yang berperan penting dalam memikat pembeli, membuat mereka nyaman dalam memilih barang belanjaan, dan mengingatkan mereka produk apa yang ingin dimiliki baik untuk keperluan pribadi, maupun untuk keperluan rumah tangga". Pada Swalayan Mouza di Kota Palu Atmosfir Toko juga memainkan peran penting dalam 


\section{Jumal Ekgnomi Trend Vol. 09 So. 02 Jufi - Desem6er 2021 E-ISSN. 2722-6565}

pembentukan pembelian tidak terencana.

Berdasarkan hasil analisis diketahui bahwa variabel store athmosphere menunjukkan bahwa pada tingkat signifikansi t 0,000 atau lebih kecil dari pada nilai alpha 0,05 membuktikan bahwa store athmosphere merupakan elemen bauran promosi ritel yang berpengaruh signifikan terhadap pembelian tidak terencana.

\section{KESIMPULAN}

Berdasarkan hasil penelitian dan pembahasan yang dilakukan untuk mengetahui pengaruh bauran promosi ritel yang terdiri dari advertising, sales promotion, personal selling, dan store athmosphere terhadap pembelian tidak terencana pada Swalayan Mouza di kota Palu sebagai mana pada bab sebelumnya, maka dapat ditarik beberapa kesimpulan penelitian sebagai berikut:

1. Bauran promosi ritel yang disusun oleh Periklanan, Promosi Penjualan, Penjualan Pribadi, dan Atmosfir Toko berpengaruh positif secara signifikan terhadap terjadinya pembelian tidak terencana oleh konsumen pada Swalayan Mouza di kota Palu.

2. Variabel Periklanan secara parsial berpengaruh positif secara signifikan terhadap terjadinya pembelian tidak terencan pada Swalayan Mouza di kota Palu.

3. Variabel Promosi Penjualan secara parsial berpengaruh positif secara signifikan terhadap terjadinya pembelian tidak terencan pada Swalayan Mouza di kota Palu.

4. Variabel Penjualan Pribadi secara parsial berpengaruh positif secara signifikan terhadap terjadinya pembelian tidak terencan pada Swalayan Mouza di kota Palu.

5. Variabel Atmosfir Toko secara parsial berpengaruh positif secara signifikan terhadap terjadinya pembelian tidak terencan pada Swalayan Mouza di kota Palu.

6. Diantara keempat variabel yang menyusun bauran promosi ritel dalam penelitian ini, variabel sales promotion merupakan variabel independen yang berpengaruh paling besar dan dinyatakan dominan terhadap terjadinya pembelian tidak terencana pada Swalayan Mouza di kota Palu.

\section{Saran-Saran}

Berdasarkan kesimpulan yang di ambil, maka penulis memberikan saran sebagai berikut:

1. Bagi pihak Swalayan Mouza di kota Palu hendaknya harus meningkatkan programprogram promosi seperti diskon, hadiah langsung, souvenir, sample, demonstrasi dan referral gift karena merupakan alasan yang kuat bagi konsumen untuk melakukan pembelian produk Swalayan 
Mouza di kota Palu.

2. Store athmosphere yang dalam penelitian ini merupakan variabel bauran promosi ritel yang memiliki nilai kontribusi paling kecil terhadap pembentukan pembelian tidak terencana harus mendapatkan perhatian serius dari pihak Swalayan Mouza di Kota Palu

3. Bagi peneliti selanjutnya sangatlah penting untuk mengembangkan penelitian ini dengan menggunakan variabel atau indikator yang berbeda baik menambah atau mengurangi sehingga mampu menghasilkan temuan yang lebih tajam dan mendalam demi kesempurnaan penelitian yang dilakukan sekarang ini

\section{DAFTAR PUSTAKA}

Akhmad, A., \& Latoki, L. (2021). KAJIAN MENGENAI KEMAMPUAN MODAL SENDIRI DALAM MENJAMIN KESELURUHAN HUTANG PERUSAHAAN (Studi pada Perusahaan Bisi International Tbk Tahun 2017-2019). Jurnal Ekonomi Trend, 9(1), 17-22. https://doi.org/10.31970/trend.v9i1.203

Assauri, Sofjan., 2004, Manajemen Pemasaran, PT. Raja Grafindo Persada, Jakarta.

Azis, A. (2019). PENGARUH FASILITAS, KEMAMPUAN DAN DISIPLIN KERJA TERHADAP KINERJA PEGAWAI KANTOR KECAMATAN TINOMBO KABUPATEN PARIGI MOUTONG. Jurnal Ekonomi Trend, $7(2), \quad 30-41$. https://doi.org/10.31970/trend.v7i2.178 Boyd, W. Harper, Walker C. Orville, and Larreche Jean-Claude, 2000,
ManajemenPemasaran. Suatu Pendekatan Strategis dengan Orientasi Global, Jilid 2,Edisi Kedua, Penerbit Erlangga, Jakarta.

Gitosudarmo, Indriyo, 1994, Manajemen Pemasaran, Edisi Pertama, Badan Penerbit Fakultas Ekonomi UGM, Yogyakarta.

Adelaar, Thomas, Susan Chang, Karen M.L, Byoungkwan Lee, Mariko Morimoto.2003. Effects of Media Formats on Emotion and Impulse buying Intent. Journal of Information Technology (December 2003) 18, 247 266. East Lansing, USA.

Arnold, Mark J and Kristy E. Reynolds. 2003. Hedonic shopping motivations.Journal of Retailing. New York University, USA.

Berman, Barry dan Joel R. Evans . 2001. Retail Management, A Strategic Approach.Prentice Hall, United States of America.

Bowes, Brad. 1998. The Effects Of Emotion And Time To Shop On Shopping Behavior In An International Airport Terminal. Brisbane Airport Corporation Limited: Griffith University, Brisbane Australia

Engel, JF, R.D Blackwell dan P.W Miniard. 1994. Consumer Behavior jilid 1 (terjemahan). $6^{\text {th }}$ edition,. Binarupa Aksara, Jakarta.

Engel, JF, R.D Blackwell dan P.W. Miniard. 1995. Consumer Behavior jilid 2 (terjemahan). $6^{\text {th }}$ edition. Binarupa Aksara, Jakarta.

Hasan, M. Ikbal. 2003. Pokok-Pokok Materi Metodologi Penelitian dan Aplikasinya.Ghalia Indonesia, Jakarta.

Hodge, Rebecca. 2004. factors Influencing Impulse Buying During an Online purchase Transaction. Tesis pada University of Waterloo. Ontario, Canada.

Kotler, P dan G Armstrong. 2001. Prinsip-prinsip Pemasaran Jilid 1. 
Edisi 8.Erlangga, Jakarta.

Levy, Michael dan Barton A. Weitz. 2001.

Retailing Management. $4^{\text {th }}$ Edition. Mc Graw Hill Irwin, New York.

Lewison, Dale M dan M. Wayne Delozier. 1989. Retailing. 3rd edition. Merril Publishing Company: Colombus, Ohio.

Lovelock, Christopher dan Lauren Wright. 2005. Manajemen Pemasaran Jasa : Alih bahasa, Agus Widyantoro. PT INDEKS, Jakarta.

Ma'ruf, Hendri. 2006. Pemasaran Ritel. PT. Gramedia Pustaka Utama, Jakarta. Muharam, S. 2001. Trend Industri Retail Indonesia Di Millenium Baru;Bagian I:Evolusi Format Retail Di Indonesia. http://www.smfranchise.com.

[11Februari 2008]

Salim, F. U. (2020). PENGARUH ADVERSITY QUOTIENT DAN KOMPETENSI TERHADAP KINERJA KARYAWAN PT. ASKES (PERSERO) PALU. Jurnal Ekonomi Trend, 8(1), 26-34. https://doi.org/10.31970/trend.v8i1.183 Simatupang, David. S. No.08/II/Agustus/2007. Hiruk Pikuk di Outlet Modern. Majalah MARKETING: hlm 28-30.

Simatupang, David. S. No.08/II/Agustus/2007. Mari Menggaet Langsung Pembeli.Majalah MARKETING: hlm 31-32.

Salim, F. U. (2021). Pengaruh Adversity Quotient Dan Kompetensi Terhadap Kinerja Karyawan Pt. Askes (Persero) Palu. Jurnal Ekonomi Trend, 8(1), 2634.

https://doi.org/10.31970/trend.v8i1.183

Afrianti, Ria 2010. Pengaruh Promosi Penjualan Terhadap Impulse Buying Pada Hypermarket Di kota Bandung.

Primanto Budi Alfian 2011. Pengaruh Aktivitas Pemasaran di dalam Ritel Modern terhadap Pembelian tidak
Terencana (Survei pada Konsumen yang Berbelanja di Giant Hypermarket, Mall Olympic Garden, Malang)

Yustrianti. Ade 2008. Pengaruh In-store Promotion Terhadap Keputusan Impulse Buying Pada Konsumen Giant Hypermarket Botani Square Bogor.

http.www.wikipedia.com

http.www.google.com 